\title{
Induction of Nestin Early Expression as a Hallmark for Mesenchymal Stem Cells Expression of PDX-1 as a Pre-disposing Factor for Their Conversion into Insulin Producing Cells
}

\author{
Marisela Martinez-Gamboa ${ }^{1,2}$, Delia Elba Cruz-Vega ${ }^{2}$, Jorge Moreno-Cuevas ${ }^{2}$, Maria Teresa Gonzalez-Garza ${ }^{2}$ \\ ${ }^{I}$ Escuela De Ciencias De La Salud, Valle de las Palmas, Universidad Autónoma de Baja California, Tijuana, B.C, CP 22263, \\ México, ${ }^{2}$ Cell Therapy Group, Escuela Nacional De Medicina, Tecnológico de Monterrey, Monterrey, CP 64710, NL, México
}

\begin{abstract}
Diabetes constitutes a worldwide epidemic that affects all ethnic groups. Cell therapy is one of the best alternatives of treatment, by providing an effective way to regenerate insulin-producing cells lost during the course of the disease, but many issues remain to be solved. Several groups have been working in the development of a protocol capable of differentiating Mesenchymal Stem Cells (MSCs) into physiologically sound Insulin Producing Cells (IPCs). In order to obtain a simple, fast and direct method, we propose in this manuscript the induction of MSCs to express NESTIN in a short time period $(2 \mathrm{~h})$, proceeded by incubation in a low glucose induced medium $(24 \mathrm{~h})$ and lastly by incubation in a high glucose medium. Samples from cell cultures incubated in high glucose medium from 12 to $168 \mathrm{~h}$ were obtained to detect the expression of INSULIN-1, INSULIN -2, PDX-1 and GLUT-2 genes. Induced cells were exposed to a glucose challenge, in order to assess the production of insulin. This method allowed us to obtain cells expressing PDX-1, which resembles a progenitor insulin-producing cell.
\end{abstract}

Keywords: Mesenchymal stem cells, PDX-1, Insulin producing cells, Nestin

\section{Introduction}

Diabetes mellitus is a chronic disease that has been present along human history and unfortunately, its prevalence in recent decades has reached pandemic proportions. The disease is characterized by a group of metabolic disorders such as chronic hyperglycemia, which is caused in

\footnotetext{
Accepted for publication November 8, 2016, Published online May 30, 2017

Correspondence to Maria Teresa Gonzalez-Garza

Cell Therapy Group, Escuela Nacional de Medicina, Tecnológico de Monterrey, Monterrey, CP 64710, NL, México

Tel: +52-81-8888-2415, Fax: +52-81-8888-2141

E-mail: mtgonzalezgarza@itesm.mx

(c) This is an open-access article distributed under the terms of the Creative Commons Attribution Non-Commercial License (http://creativecommons.org/ licenses/by-nc/4.0/), which permits unrestricted non-commercial use, distribution, and reproduction in any medium, provided the original work is properly cited.

Copyright (c) 2017 by the Korean Society for Stem Cells Research
}

some instances by an absolute or relative deficiency of insulin, the key hormone in the maintenance of normal glucose levels. Some pathological factors of diabetes are the destruction of beta cells, insulin resistance, insufficient insulin secretion in response to the stimulation of glucose, proinsulin defective synthesis, the inability to carry insulin to a mature stage, and a decrease in the proliferation of beta cells (1-3).

Even though systemic management of diabetes has improved patients quality of life, the disease remains an unsolved health problem of epic proportions. For several years, exogenous insulin for type I and some cases of type II diabetes has been the standard treatment available for patients suffering from this condition (4).

Some alternative therapies have been proposed to this treatment, like the replacement of lost beta cells by transplantation of pancreatic Islets of Langerhans (5-9), but this type of therapy confronts the problem of shortage of donors, and the need for immunosuppressive therapies 
(10). Another alternative is the transplantation of stem cells, as well as the differentiation of stem cells into insulin producing cells (IPCs), which have been developed in vitro from several protocols (11-13).

Although successful embryonic cell differentiation into insulin producing cells has been reported (14-16), the use of these cells raises severe objections due to their teratogenic capacity and ethics concerns. An alternative to these issues is the use of adult stem cells, which also have the capacity to differentiate to IPCs in vitro.

The transcription factor pancreatic duodenal homeobox 1 (Pdxl) plays a key role in the differentiation of non- $\beta$-cells into IPCs. Based on that fact, stem cells have been transfected with synthesized PDX-1 mRNA (17-19) and the best results were obtained when Nestin expression - a neurofilament present in pancreatic progenitor cells related with the maturity of IPCs (20-22) preeceded the synthesis of the transcription factor.

Regardless of the hopeful results obtained thus far, many of the proposed protocols have raised concerns due to the use of transfection technics and the propensity of neoplastic conversion of these cells, especially after an in vitro long-term culture (23).

The objective of this research is the development a short protocol for in vitro differentiation of rat bone marrow stem cells into insulin progenitor cells by induction of Nestin synthesis, followed by the expression of PDX-1, and the capability of insulin production after a glucose challenge.

\section{Materials and Methods}

\section{Ethics statement}

Animal studies were performed after approved by the Animal Ethics Committee from the Medical School at the "Instituto Tecnológico y de Estudios Superiores de Monterrey" (ITESM), Reg. 2009-Re-001. All surgeries performed in the animals were under anesthesia and all efforts were made to minimize animal suffering. Animals were housed five per cage at $20 \sim 22^{\circ} \mathrm{C}$ on a $12 / 12 \mathrm{~h}$ light/dark cycle, with food and water ad libitum.

\section{Mesenchymal Cell Isolation and Culture}

MSCs were obtained from adult male Wistar rats, weighing $\sim 220$ g. Hank's balanced salt solution (Gibco, Grand Island, NY) was used to extrude the bone marrow from femurs and the suspension was filtered using a 70 $\mu \mathrm{m}$ pore size cell strainer (BD Falcon, Bedford, MA). After centrifugation, cells were resuspended in Dulbecco's modified Eagle's medium (DMEM-F12; Gibco) containing
20\% fetal bovine serum (FBS; Gibco) and 1\% antibiotics (streptomycin-penicillin) (Gibco). This medium was used as control medium (CM). Cells were seeded in $100 \mathrm{~mm}$ culture dishes (Corning Inc., New York, NY) at $37^{\circ} \mathrm{C}$ and $5 \% \mathrm{CO}_{2}$ in a humid chamber for $24 \mathrm{~h}$. To remove nonadherent cells, cultures were washed with phosphate-buffered saline (PBS; pH 7.4) and the culture medium was replaced with DMEM-F12 containing 10\% FBS and 1\% antibiotics. Neuro-Induction Medium (NIM): NIM consisted of CM plus $0.1 \mu \mathrm{M}$ Retinoic acid (RA: Sigma-Aldrich, St. Louis, MO), $1 \mathrm{mM} \beta$-mercaptoethanol (Sigma-Aldrich), $2 \mathrm{mM}$ glutamine (Invitrogen, Grand Island, NY), $10 \mathrm{ng} / \mathrm{ml}$ fibroblast growth factor 2 (FGF2; Sigma-Aldrich), 0.2\% dimethyl sulfoxide (DMSO;Sigma-Aldrich), $40 \mathrm{ng} / \mathrm{ml}$ of epithelial growth factor (EGF; Invitrogen) and $0.5 \mathrm{mM}$ 3-isobutyl-1-methylxanthine (Sigma-Aldrich). Low glucose predifferentiation medium (LGM): LGM consisted in L-DMEM (5.6 mM glucose) (Gibco) containing 20\% FBS and 1\% antibiotics plus $10 \mathrm{mM}$ Nicotinamide, $0.1 \mu \mathrm{M}$ Retinoic acid, $1 \mathrm{mM} \beta$-mercaptoethanol, $4 \mathrm{mM}$ L-glutamine, $0.1 \%$ DMSO. High glucose PDX-1 Induction medium (HGM): HGM consisted in (L-DMEM plus 10\% FBS, 3.5 g glucose (25 $\mathrm{mM}$ glucose) and $1 \%$ antibiotics.

\section{Induction protocol}

Samples of $5 \times 10^{4}$ cells were seeded on a 24 wells microplate treated with poly-L-lysine (Sigma-Aldrich) and incubated for 2, 4, 6 and $12 \mathrm{~h}$ in IM. At the end of each time period, the medium was removed and cells washed with PBS. Total RNA was extracted in order to determinate the time of Nestin expression, this time was considered as the "pre-incubation goal" and used for the pre-differentiation protocol. After $24 \mathrm{~h}$ of incubation in a low glucose medium (LGM), the medium was removed and replaced by a high glucose medium (HGM). Cultures were incubated for seven days; the medium was change with fresh HGM every three days until reaching seven days of culture. Samples for immunocytochemistry and RT-PCR analysis were collected at a specified time between 12 to 168 h. Additional cells were cultured directly with HGM, without pre-incubation with NIM or LGM and analyzed as experimental cultures. All cultures were mantained at $35^{\circ} \mathrm{C}$ and $5 \% \mathrm{CO}_{2}$.

\section{Immunocytochemistry}

Circular glass slides treated with poly-L-lysine (Sigma Chemical Co., St. Louis, Missouri) were placed in 24-well microplates and cells seeded at a density of $1 \times 10^{5}$ cells/well. After performing the induction protocol, cells were fixed in $4 \%$ paraformaldehyde for $10 \mathrm{~min}$ and were 
washed three times with PBS ( $\mathrm{pH} 7.4$ ). Cells were permeabilized using $0.3 \%$ Triton $\mathrm{X}-100$ in PBS for $5 \mathrm{~min}$. Non-specific antibody reactions were blocked with $5 \%$ BSA in PBS for $1 \mathrm{~h}$. Next, cells were incubated overnight at $4^{\circ} \mathrm{C}$ with primary mouse monoclonal antibodies diluted in PBS containing 1\% BSA. The monoclonal mouse antibodies and dilutions used in the experiment were: Anti-nestin mouse monoclonal $(10 \mu \mathrm{g} / \mathrm{ml}$; R\&D Systems, Minneapolis, MN), Anti-insulin (Sigma), Anti-Glut-2 goat polyclonal (Santa Cruz Biotechnology, Santa Cruz, CA), Anti-PDX-1 goat polyclonal IgG (Santa Cruz Biotechnology), and as secondary antibody was used Anti-mouse IgG antibody conjugated goat Rhodamida (Inmunopure ${ }^{(\mathbb{}}$ ) and Anti-mouse IgG antibody conjugated goat FITC (Pierce Biotechnology, Rockford, IL), and goat anti-mouse IgG-FITC (Santa Cruz Biotechnology). Cells were washed three times with PBS and incubated with secondary goat anti-mouse $\mathrm{Fc}^{-}$fluorescein isothiocyanate (1:400; Thermo Fisher Scientific, Pierce Biotechnology, Rockford, IL) for $2 \mathrm{~h}$ in the dark. Cells were incubated for $1 \mathrm{~min}$ in propidium iodide $(0.01 \mathrm{mg} / \mathrm{ml}$; Fluka, Toluca, Mexico) or 4',6-diamidino-2-phenylindole (DAPI; Santa Cruz Biotechnology) to counterstain the nuclei. Cells were analyzed using a fluorescence microscope (Imager Z1; Zeiss, Jena, Germany). Images were obtained using an Axiocam HRm camera system (Zeiss, New York, NY) coupled to the microscope.

\section{RNA Isolation and Reverse Transcription Polymerase Chain Reaction (RT-PCR)}

Total RNA was isolated from undifferentiated mesenchymal cells and from HGM incubated cells, using a binding silica column kit (GenElute Mammalian Total RNA; Sigma-Aldrich). The amount and quality of total RNA was determined using a GeneQuant pro spectrophotometer (Amersham Biosciences, Cambridge, UK). RT-PCR was performed using a PX2 Thermo thermal cycler (Thermo Fisher Scientific), one-step reactions (Qiagen, Crawley, UK) and the following primer targets: glyceraldehyde-3-phosphate-dehydrogenase (GAPDH; sense, GGTGAAGGTCGGTGTGA, and antisense, CATGAGCCCTTCCACGA. NESTIN; sense, AACCACAGGAGTGGGAACTG, and antisense TCTGGCATTGACTGAGCAAC. INSULIN-1; sense, GGGAACGTGGTTTCTTCTACAC, and antisense GTGGTGGACTCAGTTGCAGTAG. INSULIN-2; sense, ACCTTTGTGGTTCTCACTTGGT, and antisense GTAGAGAGAGCAGATGCTGGTG.

GLUT-2; CTGGGAAGAAGAGACTGAAGGA, and antisense ATACGCTTCTTCCAGCAATGAT. PDX-1; AACCGGAGGAGAATAAGAGGAC, and antisense CTTGTGT-

\section{GTGGCGTTTAGGTTA.}

\section{Insulin detection}

For insulin detection, cells in HGM culture from each incubation time $(12 \sim 168 \mathrm{~h})$ were washed five times with Krebs-Ringer buffer and incubated for $2 \mathrm{~h}$ with the same buffer to ensure removal of glucose; those cells were stimulated with the addition of HGM and incubated at $35^{\circ} \mathrm{C}$ and $5 \% \mathrm{CO}_{2}$, for 60 minutes. The supernatant were analyzed with ELISA kit specific for rat insulin (Alpco Diagnostics, Salem, NH). Absorbance was read in the Synergy HT Microplate reader at $450 \mathrm{~nm}$. The absorbance data standards, controls and samples were recorded with Gen5 software.

\section{Dithizone staining}

Cells in HGM medium cultured for $168 \mathrm{~h}$ (St Luis, MO, USA) were incubated at $37^{\circ} \mathrm{C}$ for $30 \mathrm{~min}$ in Dithizone (DTZ) (Sigma-Aldrich). In vitro DTZ staining was performed by adding $10 \mu 1$ stock solution to $1 \mathrm{ml}$ culture medium. Stock solution was prepared by dissolving $50 \mathrm{mg}$ DTZ in $5 \mathrm{ml}$ dimethyl sulfoxide [Zhang L, 2005]. After staining, the wells were rinsed three times with Krebs-Ringer buffer and crimson-red-stained clusters were examined with a microscope to determinate the number of DTZ positive cells.

\section{Statistical analysis}

Each experiment was performed in triplicates with tree different batches of mesenchymal stem cells each. The data was performed using Minitab software 14 through an analysis of variance (ANOVA).

\section{Results}

\section{Differentiation of MSC to NESTIN expression}

In order to determinate the point of Nestin synthesis induction, cells were incubated in NIM for 2 to $12 \mathrm{~h}$. After this time range was achieved, RNA was obtained. RT-PCR showed an increase of NESTIN expression as early as 2 $\mathrm{h}$ of incubation (Fig. 1A). Immunochemistry also show nestin distribution inside the cytoplasm at $12 \mathrm{~h}$ after induction (Fig. 1B). Considering that $2 \mathrm{~h}$ of incubation in NIM was capable to induce nestin synthesis this time of pre-incubation was choosed to continue with the pre-diferentiation protocol. Cells incubated with CM did not express NESTIN. 


\section{Differentiation of MSC into IPC. Gene expression by RT-PCR}

mRNA of cells incubated for 30 min with HGM showed positive gene expression for all analyzed genes after $12 \mathrm{~h}$ of incubation. The glucose channel GLUT-2 was detected at its highest level after HGM of $96 \mathrm{~h}$ incubation. The transcription factor PDX-1 showed its highest transcription level at $48 \mathrm{~h}$, and went slightly down until 168 h. INSULIN-1 and INSULIN-2 were positive on all analyzed samples, showing a sligth expression decrease after $72 \mathrm{~h}$ of incubation and a recuperation expression after medium change. Those samples colected after medium change went down again and reach a lowest point at 168

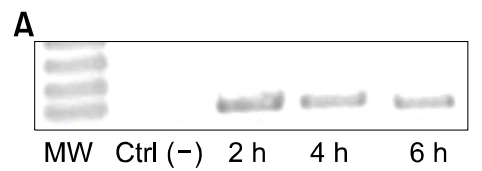

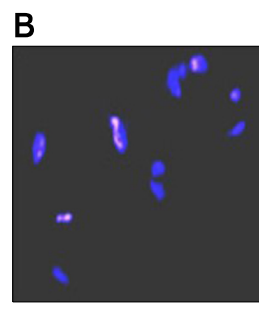

DAPI

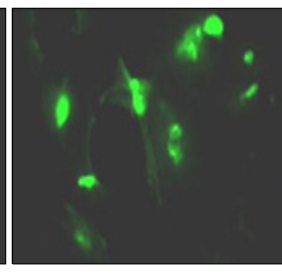

FITC

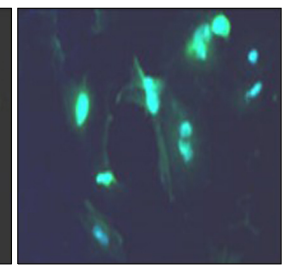

DAPI-FITC
$12 \mathrm{~h}$

Fig. 1. Nestin expression after mesencymal stem cells incubation with neuro induction medium (NIM). (A) Representative images of agarose electrophoresis of RT-PCR products for NESTIN. Lane 1: molecular weight markers. Lane 2: cells grown in DMEM-F12 (Ctrl). Lanes 3-5: cells grown in neuro-induction médium after 2, 4 and $6 \mathrm{~h}$ of incubation with NIM. (B) Representative images of immunofluorescence detection of nestin. Positive staining detection of nestin by immuncytochemistry (Green) after $12 \mathrm{~h}$ of incubation with NIM. The nucleus is labeled with 4',6-diamidino-2-phenylindole (DAPI). h. Samples obtained after 60 min of stimulation showed highest GLUT-2 expression at $96 \mathrm{~h}$. PDX-1 were detected from $12 \mathrm{~h}$ of HGM change. INSULIN-1 exhibed less expression than INSULIN-2, nevertheless it was observed in all analyzed samples. Non of the control cultures showed a positive transcription for these genes (Fig. 2).

\section{Immunocytochemical Analysis of Lineage-Specific Markers}

Immunocytochemistry imaging of cells incubated according to the induction protocol, showed positive labeling of GLUT-2, PDX-1 and INSULIN after $60 \mathrm{~min}$ of incubation with HGM (Fig. 3), in agreement with RT-PCR results (Fig. 3) Non of the control cultures showed a pos-

\section{A}

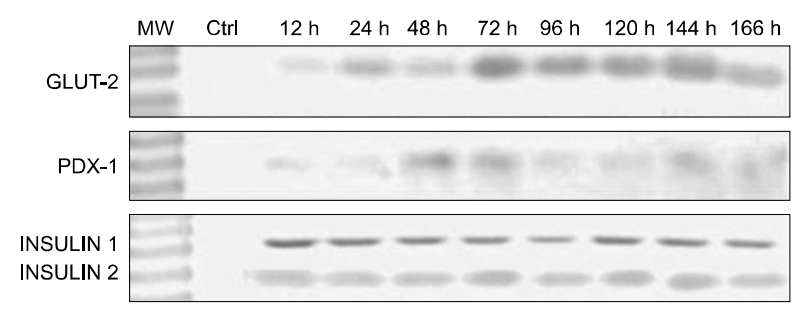

B

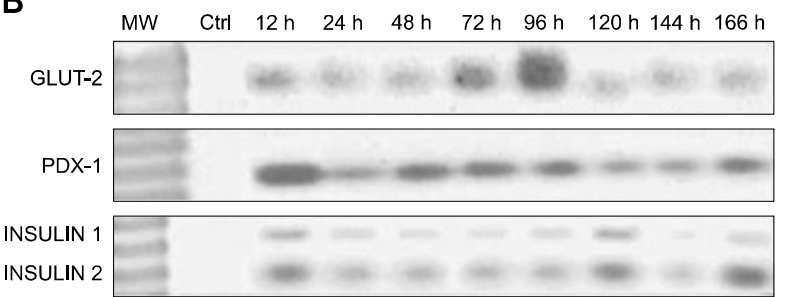

Fig. 2. Agarose electrophoresis of RT-PCR products for GLUT-2, PDX-1 and INSULIN 1,2 gene expression from mRNA samples of cell incubated with high glucose medium (HGM) for $12 \mathrm{~h}$ to 168 h. Samples were taken after $30 \mathrm{~min}(\mathrm{~A})$ or $60 \mathrm{~min}(\mathrm{~B})$ of glucose stimulation.
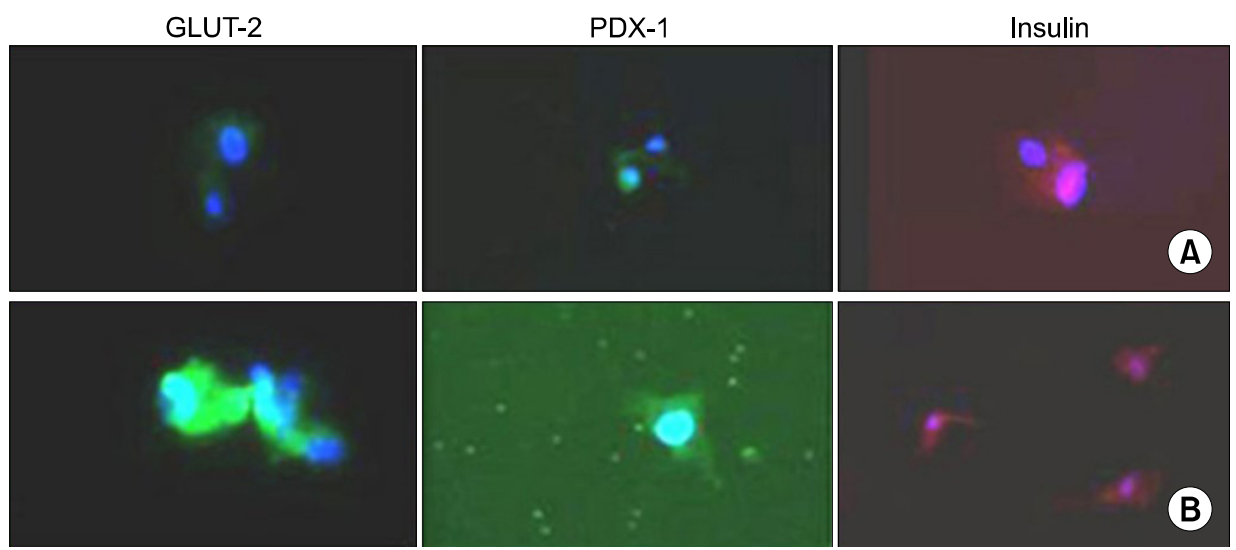

Fig. 3. Immunocytochemistry image for GLUT-2 (green), PDX-1 (green) and cytoplasmic insulin (red) of cells from culture incubated in high glucose medium (HGM), washed and stimulated. (A) after $30 \mathrm{~min}$ of incubation with glucose $25 \mathrm{mM}$ and (B) after 60 min of glucose stimulation. 


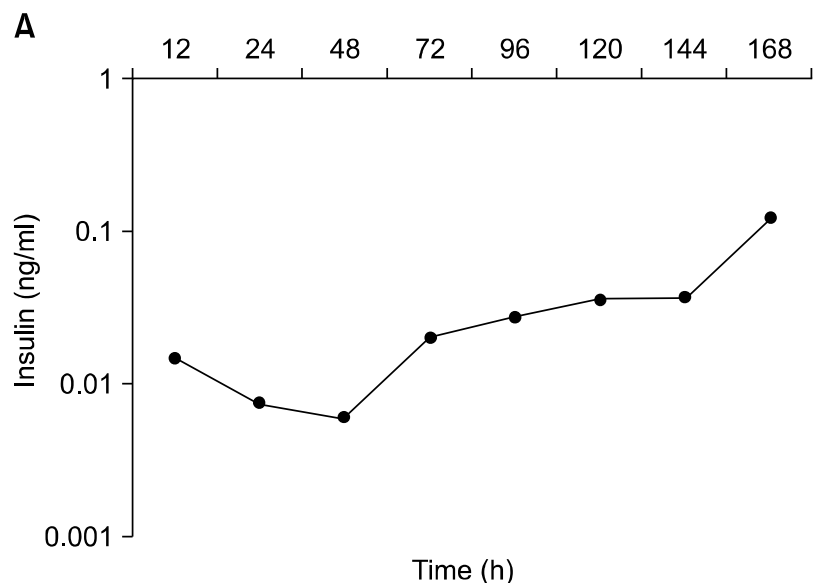

B

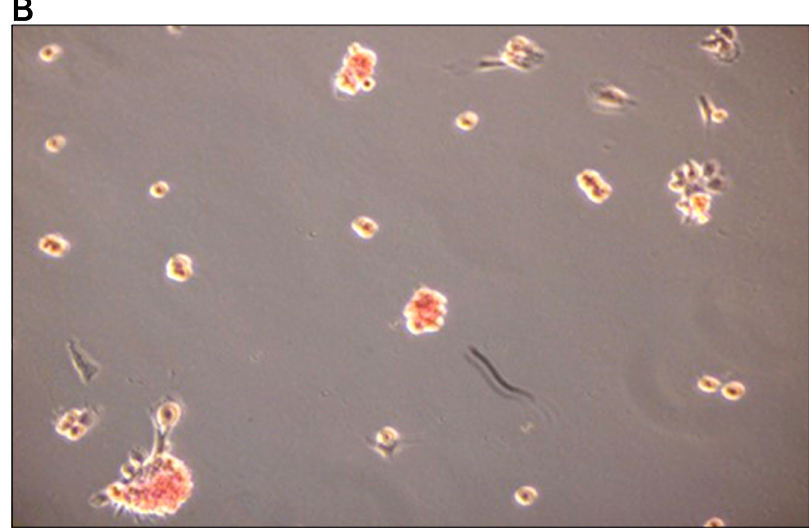

Fig. 4. Insulin detection. (A) Graphic representation of secreted insulin detected by EIA after mesenchymal stem cells pre-incubation in neuro differentiation medium (NIM) for $2 \mathrm{~h}$ and then incubated with high glucose medium (HGM). Measures were performed from samples obtained between 12 to $168 \mathrm{~h}$. (B) Microphotagraphy of cytosolic insulin detected by dithiozone staining after mesenchymal stem cells pre-incubation in (NIM) for $2 \mathrm{~h}$ and them incubated with HGM for $168 \mathrm{~h}$.

itive mark for these proteins.

\section{Insulin detection}

Samples colected from cells incubated in HGM at 12 to $168 \mathrm{~h}$ were use to performed EIA in order to detect secreted insulin. Results showed detectable values of secreted insulin consistent with $72 \mathrm{~h}$ of culture (Fig. 4A).

\section{Dithizone staining}

In order to verify the production of insulin by IPCs, dithizone staining was used. Dithizone binds to insulin and turns red. Staining red or brown indicates the presence of insulin granules in cell aggregates. Cells from culture incubated with HGM confirm Insulin-containing cells in spheroids after $168 \mathrm{~h}$ of incubation. The dithizione positive cells were in the $80 \sim 90 \%$ range (Fig. $4 \mathrm{~B}$ ).

\section{Discussion}

Nestin is a marker for pancreatic stem cells and for islet progenitor cells, playing and important role in the stemness and differentiation of stem cells into insulin-secreting cells (24-28). In pancreas, NESTIN expression is considered an intermediate regulator governing the proliferation and differentiation of new islet cells (20). The above explains why this protocol was first oriented towards NESTIN expression. Several protocols have described the induction of NESTIN expression on embryonic and adult stem cells, with the caveat that the process takes from 1 to 7 days $(27,29-32)$. The induction medium used on this research, was capable to promote MSCs to express NESTIN as early as $2 \mathrm{~h}$. Nestin positive cells were important because they represent the first step to re-directed and activate signaling pathways that lead the expression of the PDX-1 gene. It is well know that PDX-1 is a transcription factor involved on embryonic development of the pancreas, and in the normal pancreatic islet of adult organisms, works regulating the expression of INSULIN and GLUT-2 among other genes.

PDX-1 is an important transcription factor expressed throughout the epithelium of early pancreatic buds and restricted to beta cells in the adult animal, where it plays a role in INSULIN expression and glucose response. Furthermore, exogenous PDX-1 expression during in vitro differentiation of embryonic cells clearly enhanced the expression of INSULIN. Based on those facts, the transfection of adult stem cells with vectors carrying the PDX-1 gene has been used to obtain IPCs (17, 19, 33-35), including nestin positive cells trasfected with plasmids carrying rat Pdx-1 and BTC genes or PDX-1 mRNA allow to induce MSCs into the islet like cells (18-22).

Until now several protocols have been proposed to directly differentiated MSC into IPCs and although they have been successful, their approach takes more than 2 weeks and several steps to obtain IPCs $(15,31,36-39)$. In 2012, there was a protocol develop by Her et al. (26), which included four steps to obtain Nestin positive cells from human blood derivate stem cells incubated in a three-dimensional culture. These cells express nestin after eight days and then differentiate into IPCs. Our protocol proposes three short steps to obtain IPCs from rat bone marrow on less than 7 days. In fact, results show that cells incubated on differentiation medium as early as $24 \mathrm{~h}$ were capable to express INSULIN-1, INSULIN-2, PDX-1 and GLUT-2, after a glucose challenge. Based on these results and following the same scheme, we are proposing this protocol to be followed on stem cells from different sources, 
to confirm the early response of nestin positive cells diferentiation into IPCs precursors.

\section{Conclusion}

The induction of mesenchymal stem cells to early express NESTIN and the following incubation on differentiation medium, allowed these cells to express INSULIN, PDX-1 and GLUT-2 genes in response to glucose stimulation. This precursor cells will be and important recourse to cell replacement of progenitor pancreatic cells.

\section{Acknowledgments}

This work was partially funded by endowments from ITESM (cat-134), the Zambrano-Hellion Foundation and Clarion Fundation.

\section{Competing Interests}

The authors declare that there is no conflict of interests regarding the publication of this paper.

\section{References}

1. Atkinson MA. The pathogenesis and natural history of type 1 diabetes. Cold Spring Harb Perspect Med 2012;2 pii: a007641 doi: 10.1101/cshperspect.a007641

2. Atkinson MA, von Herrath $M$, Powers AC, Clare-Salzler M. Current concepts on the pathogenesis of type 1 diabetes--considerations for attempts to prevent and reverse the disease. Diabetes Care 2015;38:979-988

3. Halban PA. 50 years forward: beta cells. Diabetologia 2015;58:1688-1692

4. Atkinson MA, Eisenbarth GS. Type 1 diabetes: new perspectives on disease pathogenesis and treatment. Lancet 2001;358:221-229

5. Benhamou PY, Oberholzer J, Toso C, Kessler L, Penfornis A, Bayle F, Thivolet C, Martin X, Ris F, Badet L, Colin C, Morel P; GRAGIL consortium. Human islet transplantation network for the treatment of Type I diabetes: first data from the Swiss-French GRAGIL consortium (1999-2000). Groupe de Recherche Rhin Rhône Alpes Genève pour la transplantation d'Ilots de Langerhans. Diabetologia 2001;44:859-864

6. Noguchi H. Pancreatic islet transplantation. World J Gastrointest Surg 2009;1:16-20

7. Sakata N, Sumi S, Yoshimatsu G, Goto M, Egawa S, Unno M. Encapsulated islets transplantation: Past, present and future. World J Gastrointest Pathophysiol 2012;3:19-26

8. Kaddis JS, Hanson MS, Cravens J, Qian D, Olack B, Antler M, Papas KK, Iglesias I, Barbaro B, Fernandez L, Powers AC, Niland JC. Standardized transportation of human islets: an islet cell resource center study of more than 2,000 shipments. Cell Transplant 2013;22:1101-1111
9. Krishnan R, Alexander M, Robles L, Foster CE 3rd, Lakey JR. Islet and stem cell encapsulation for clinical transplantation. Rev Diabet Stud 2014;11:84-101

10. Montanya E. Islet- and stem-cell-based tissue engineering in diabetes. Curr Opin Biotechnol 2004;15:435-440

11. Bhonde RR, Sheshadri P, Sharma S, Kumar A. Making surrogate $\beta$-cells from mesenchymal stromal cells: perspectives and future endeavors. Int J Biochem Cell Biol 2014; 46:90-102

12. Hashemian SJ, Kouhnavard M, Nasli-Esfahani E. Mesenchymal Stem Cells: Rising Concerns over Their Application in Treatment of Type One Diabetes Mellitus. J Diabetes Res 2015 doi: 10.1155/2015/675103

13. Sabek OM, Farina M, Fraga DW, Afshar S, Ballerini A, Filgueira CS, Thekkedath UR, Grattoni A, Gaber AO. Three-dimensional printed polymeric system to encapsulate human mesenchymal stem cells differentiated into islet-like insulin-producing aggregates for diabetes treatment. J Tissue Eng 2016;7:2041731416638198 doi: 10.1177/ 2041731416638198

14. Lumelsky N, Blondel O, Laeng P, Velasco I, Ravin R, McKay R. Differentiation of embryonic stem cells to insulin-secreting structures similar to pancreatic islets. Science 2001;292:1389-1394

15. Mohamad Buang ML, Seng HK, Chung LH, Saim AB, Idrus RB. In vitro generation of functional insulin- producing cells from lipoaspirated human adipose tissue-derived stem cells. Arch Med Res 2012;43:83-88

16. D'Amour KA, Bang AG, Eliazer S, Kelly OG, Agulnick AD, Smart NG, Moorman MA, Kroon E, Carpenter MK, Baetge EE. Production of pancreatic hormone-expressing endocrine cells from human embryonic stem cells. Nat Biotechnol 2006;24:1392-1401

17. Yuan H, Li J, Xin N, Zhao Z, Qin G. Expression of Pdxl mediates differentiation from mesenchymal stem cells into insulin-producing cells. Mol Biol Rep 2010;37:4023-4031

18. Van Pham P, Thi-My Nguyen P, Thai-Quynh Nguyen A, Minh Pham V, Nguyen-Tu Bui A, Thi-Tung Dang L, Gia Nguyen K, Kim Phan N. Improved differentiation of umbilical cord blood-derived mesenchymal stem cells into insulin-producing cells by PDX-1 mRNA transfection. Differentiation 2014;87:200-208

19. Wang XL, Hu P, Guo XR, Yan D, Yuan Y, Yan SR, Li DS. Reprogramming human umbilical cord mesenchymal stromal cells to islet-like cells with the use of in vitro-synthesized pancreatic-duodenal homebox 1 messenger RNA. Cytotherapy 2014;16:1519-1527

20. Zulewski H, Abraham EJ, Gerlach MJ, Daniel PB, Moritz W, Müller B, Vallejo M, Thomas MK, Habener JF. Multipotential nestin-positive stem cells isolated from adult pancreatic islets differentiate ex vivo into pancreatic endocrine, exocrine, and hepatic phenotypes. Diabetes 2001;50:521-533

21. Zhang L, Hong TP, Hu J, Liu YN, Wu YH, Li LS. Nestin-positive progenitor cells isolated from human fetal pancreas have phenotypic markers identical to mesen- 
chymal stem cells. World J Gastroenterol 2005;11:2906-2911

22. Li L, Li F, Qi H, Feng G, Yuan K, Deng H, Zhou H. Coexpression of Pdxl and betacellulin in mesenchymal stem cells could promote the differentiation of nestin-positive epithelium-like progenitors and pancreatic islet-like spheroids. Stem Cells Dev 2008;17:815-823

23. Tang DQ, Wang Q, Burkhardt BR, Litherland SA, Atkinson MA, Yang LJ. In vitro generation of functional insulin-producing cells from human bone marrow-derived stem cells, but long-term culture running risk of malignant transformation. Am J Stem Cells 2012;1:114-127

24. Kim SY, Kim HI, Kim TH, Im SS, Park SK, Lee IK, Kim KS, Ahn YH. SREBP-1c mediates the insulin-dependent hepatic glucokinase expression. J Biol Chem 2004;279: 30823-30829

25. Kim SY, Lee S, Hong SW, Min BH, Lee KU, Bendayan $M$, Park IS. Nestin action during insulin-secreting cell differentiation. J Histochem Cytochem 2010;58:567-576

26. Hur J, Yang JM, Choi JI, Yun JY, Jang JH, Kim J, Kim JY, Oh IY, Yoon CH, Cho HJ, Park YB, Kim HS. New method to differentiate human peripheral blood monocytes into insulin producing cells: Human hematosphere culture. Biochem Biophys Res Commun 2012;418:765-769

27. Wei R, Yang J, Hou W, Liu G, Gao M, Zhang L, Wang H, Mao G, Gao H, Chen G, Hong T. Insulin-producing cells derived from human embryonic stem cells: comparison of definitive endoderm- and nestin-positive progenitor-based differentiation strategies. PLoS One 2013; 8:e72513

28. Milanesi A, Lee JW, Xu Q, Perin L, Yu JS. Differentiation of nestin-positive cells derived from bone marrow into pancreatic endocrine and ductal cells in vitro. J Endocrinol 2011;209:193-201

29. Chen L, He DM, Zhang Y. The differentiation of human placenta-derived mesenchymal stem cells into dopaminergic cells in vitro. Cell Mol Biol Lett 2009;14:528-536

30. Liu Z, Long X, Li J, Wei L, Gong Z, Fang W. Differentiation of temporomandibular joint synovial mesenchymal stem cells into neuronal cells in vitro: an in vitro study. Cell Biol Int 2011;35:87-91

31. Kim SJ, Choi YS, Ko ES, Lim SM, Lee CW, Kim DI. Glucose-stimulated insulin secretion of various mesenchymal stem cells after insulin-producing cell differentiation. J Biosci Bioeng 2012;113:771-777

32. Mohammad MH, Al-Shammari AM, Al-Juboory AA, Yaseen NY. Characterization of neural stemness status through the neurogenesis process for bone marrow mesenchymal stem cells. Stem Cells Cloning 2016;9:1-15

33. Hui H, Perfetti R. Pancreas duodenum homeobox-1 regulates pancreas development during embryogenesis and islet cell function in adulthood. Eur J Endocrinol 2002;146: 129-141

34. Miyazaki S, Yamato E, Miyazaki J. Regulated expression of pdx-1 promotes in vitro differentiation of insulin- producing cells from embryonic stem cells. Diabetes 2004; 53:1030-1037

35. Allahverdi A, Abroun S, Jafarian A, Soleimani M, Taghikhani M, Eskandari F. Differentiation of human mesenchymal stem cells into insulin producing cells by using a lentiviral vector carrying PDX1. Cell J 2015;17:231-242

36. Tang DQ, Cao LZ, Burkhardt BR, Xia CQ Litherland SA, Atkinson MA, Yang LJ. In vivo and in vitro characterization of insulin-producing cells obtained from murine bone marrow. Diabetes 2004;53:1721-1732

37. Sun Y, Chen L, Hou XG, Hou WK, Dong JJ, Sun L, Tang KX, Wang B, Song J, Li H, Wang KX. Differentiation of bone marrow-derived mesenchymal stem cells from diabetic patients into insulin-producing cells in vitro. Chin Med J (Engl) 2007;120:771-776

38. Chen LB, Jiang XB, Yang L. Differentiation of rat marrow mesenchymal stem cells into pancreatic islet beta-cells. World J Gastroenterol 2004;10:3016-3020

39. Fu Z, Gilbert ER, Liu D. Regulation of insulin synthesis and secretion and pancreatic Beta-cell dysfunction in diabetes. Curr Diabetes Rev 2013;9:25-53 